\title{
Right to Happiness - A Challenge for International Organizations and Governments
}

\author{
Titus Corlatean
}

\author{
Ph.D., Associate Professor, „Dimitrie Cantemir” Christian University, Bucharest, Romania; \\ Visiting scholar at Harvard University/Center for the study of World Religions (2018/2019)
}

\begin{abstract}
Through all his life, the humans seek happiness. Across the world, people aspire to live happily without fear to something or someone, and in harmony with God or with nature. In a world shaken by economic crisis, natural disasters or armed conflicts, life has shown that to be truly happy, in addition to material wealth, people also need spiritual wellbeing. We need a new paradigm of sustainable development. Economic wellbeing, social and a healthy environment together define the concept of happiness on a global scale. This might be implemented through a generic index named the gross global happiness index. $\mathrm{UN}, \mathrm{OECD}, \mathrm{EC}$ bodies and governments of some countries have understood that only economic indicators are not enough to develop public policies able to find solutions to the problems of the contemporary world. Economic data should be complemented with information designed to measure quality of life not only in material terms. The international community should promote sustainable development capable of ensuring every opportunity to seek happiness. The debates on the subject, held at international level could result, among other things, that the right to happiness should be recognized legally binding. There are already proposals for inclusion in the Charter of Fundamental Rights of the European Union. This paper is a call for continued efforts made by the governments of some countries and several international bodies towards the elaboration of public policies able to lead to sustainable development and improving the quality of life.
\end{abstract}

KEYWORDS: right to happiness, prosperity, human rights, sustainable development, public policy, GDP, economic growth, international community, the United Nations

\section{Introduction}

Happiness is a fundamental goal of humanity. We all strive to achieve this. Lately, economic crises, environmental disasters or armed conflicts are increasingly difficult to achieve this goal for many people. A debate was launched on the international level in order to find solutions to such problems. One of the topics proposed for debate is that of implementation of new public policies that focus on human well-being, not just economic growth. Such an approach should be based on sustainable development solutions to combat poverty and to promote the welfare and happiness of the people. For that, it would require indicators capable of measuring the degree of human happiness. A proposal in this regard is the socalled „Gross National Happiness" index, aimed at completing the GDP (Gross Domestic Product), which covers only the economic side of the issue. „Gross National Happiness” could be an indicator to harmonize the business side of the company, which keeps the environment and cultural and spiritual values of mankind. The accumulation of wealth is not enough in itself. To bring happiness, people should be completedwith both material and spiritual wealth and also reconciliation with themselves, but mainly with the Creator, even before achieving reconciliation with nature. Lately, more and more voices are heard internationally that require new public policies, closer to people's real needs. Political leaders speak about the need to give more importance to sustainable development, to the spiritual side of being, and not just to policies aimed at assuring economic growth.

\section{International documents, policies and mechanisms}

In August 2011, the UN General Assembly adopted the Resolution 65/309 entitled: "Happiness: towards a holistic approach to development", which states, inter alia:

„Conscious that the pursuit of happiness is a fundamental human goal, Cognizant that happiness as a universal goal and aspiration embodies the spirit of the Millennium Development Goals, Recognizing that the gross domestic product indicator by nature was not designed to and does not adequately reflectthe happiness and well-being of people in a country, Conscious that unsustainable patterns of production and consumption can impede sustainable development, and 
recognizing the need for a more inclusive, equitable and balanced approach to economic growth that promotes sustainable development, poverty eradication, happiness and well-being of all peoples, Acknowledging the need to promote sustainable development and achieve the Millennium Development Goals,

1. Invites Member States to pursue the elaboration of additional measures that better capture the importance of the pursuit of happiness and well-being in development with a view to guiding their public policies;

2. Invites those Member States that have taken initiatives to develop new indicators, and other initiatives, to share information there on with the Secretary-General as a contribution to the United Nations development agenda, including the Millennium Development Goals; ...Invites the Secretary-General to seek the views of Member States and relevant regional and international organizations on the pursuit of happiness and well-being and to communicate such views to the General Assembly at its sixtyseventh session for further consideration" (UN General Assembly, Resolution 65 /309, 2011).

Following this Resolution, in April 2012, at the initiative of Bhutan, at UN headquarters in New York held a high-level meeting entitled „Wealth and Happiness: Defining a new economic paradigm”, attended by hundreds of representatives of governments Member States of the UN, the religious organizations, academia and civil society.

In 1970, Bhutan has introduced a new system for measuring national prosperity, focused on people's welfare, which gradually replaced indicators that economic productivity, resulted in an indicator called "Gross National Happiness" as an alternative to GDP. One such indicator consider criteria other than strictly economic, such as the distribution of resources, sustainability, health, human rights and education.

And also due to the same Resolution adopted in August 2011 by the UN General Assembly, March 20 was declared International Day of Happiness. During the first celebration of this day, on March 20, 2013, UN Secretary General Ban Ki Moon (2013), stated that: „At last year's Rio+20 United Nations Conference on Sustainable Development, United Nations Member States agreed on the need for a balanced approach to sustainable development by integrating its three pillars economic growth, social development and environmental protection. They recognized that in order to better inform policy decisions, broader measures of progress should complement gross domestic product. I am encouraged by the efforts of some Governments to design policies based on comprehensive well-being indicators. I encourage others to follow suit."

UN Example was followed by European Economic and Social Committee (EESC 2014), a consultative body of the European Union, which in June 2014 organized a debate called "Let's talk about happiness - beyond the GDP". On this occasion, EUROSTAT, the EU agency in charge of statistical indicators to use in his studies to measure sustainability and quality of life. In addition, the EESC launched the idea of a public debate on the review of Europe 2020, to include among the objectives of the strategy, in addition to creating conditions for sustainable economic growth (job creation, research, energy, environment, education, social inclusion poverty reduction) objectives regarding spiritual welfare and happiness.

On this occasion it was reminded that some EU Member States they have already taken steps in this direction. For example, in 2012 the British government published the first national index of happiness, the German Parliament has set up a commission to examine the subject, Austria had already published the first official statistics on the national welfare and happiness, and the French government established a national model for achieving a national index of happiness. Moreover, in 2008, the French Government asked a committee led by renowned professor of economics Joseph Stiglitz, to conduct a study on the measurement of economic performance. The Commission's report on measuring economic performance and social progress was published in September 2009. The aim of the committee was to identify the limits of GDP as an indicator of economic performance and social progress and determine whether other indicators could be considered for measurement in May proper social progress. One of the main conclusions of the report was the necessity to shift emphasis from measuring economic production to measuring people's well-being. „Measuring well-being is important because there is a significant difference between the information contained in the 
information about GDP and what really matters to people's welfare. Recommendation No. 10: Measuring well-being both objectively and subjectively provide essential information about the quality of people's lives. Statistical studies should include questions relating to the evaluation of people's lives, what they expect from life and their priorities" (Stiglitz, Sen, \& Fitoussi 2009, 12). Subjective well-being encompasses different aspects: cognitive assessments on personal life, happiness, satisfaction, positive emotions such as pride or joy that and negative, such as pain or concern. Each of these should be measured to have a complete picture on the quality of people's lives, but also to better understand the causes that determine such developments beyond the material aspects, quantitative. Official statistics should include in future studies to make this kind of measurement and data to be made available for the government (Stiglitz, Sen, \& Fitoussi 2009, 16).

In September 2013, the „Network Solutions for Sustainable Development” (UN SDSN) published, under the auspices of the UN Secretary General, Ban Ki-moon, the second edition of the "Report on Global Happiness", which measure overall level of well-being of nations and seek solutions to improve sustainable development worldwide. The report was a ranking of countries by a number of components of well-being, and highlighted other similar initiatives such as ,better life index" to measure well-being, conducted by the Organization for Economic Cooperation and Development (OECD) and United Nations Development Programme report. The report's findings were that noticeable improvement of quality of life were recorded in Latin America and the Caribbean, while in contrast, decreases were recorded for the indicator in areas affected by economic and financial crisis, Western Europe and other industrialized western countries, or the instability generated by social or political crisis, North Africa and the Middle East. Overall, despite the impact of the crisis in 2008 (World Happiness Report 2013, 11-13), the report finds that the world had become a little happier and more generous than in 2008-2013.

Among the 156 countries that had been analized,Denmark, Norway, Switzerland, the Netherlands and Sweden had the highest ranking while countries such as Rwanda, Burundi, Central Africa, Benin and Togo were at the bottom of the ranking. United States ranked 17th, United Kingdom 22nd, Germany ranked 27th, Republic of Moldova 53rd, Russia 68th and Romania 90th (World Happiness Report 2013, 22-23). According to the report, GDP per capita increased in almost all regions: in Central and Eastern Europe, in the Community of Independent States (CIS), in Latin America and South East Asia, with the exception of industrialized countries (USA, Canada, New Zealand, Australia).The level of perception of corruption has undergone significant improvements (low corruption) in Latin America, Western Europe, Eastern Asia, but has worsened (high level of corruption) in North America, Australia, New Zealand, North Africa and Sub - Saharan Africa and the Middle East.

The level of generosity had grown significantly in Asia, Central and Eastern Europe and the CIS, but had fallen dramatically in Western Europe, Latin America, North Africa and Sub-Saharan Africa and the Middle East. But the main indicator was lower living standards, according to the report, the decline opportunities to make their own decisions, especially due to the reduction in the number of public services available. Within the states most affected by the economic crisis in Europe (Greece, Spain, Portugal and Italy), there was a decrease of generosity and a growing distrust in state institutions due to widespread corruption (World Happiness Report 2013, 16-17).

In times of crisis, the reaction of the state is essential to retain people's confidence in government policies. If people believe that state policy will be able to help them out of the crisis, the difficulties will be overcome more easily. But if people lose confidence in state institutions will channel their discontent against the state. This explains the current skepticism about the European Union and the wave of populism that cmay be noted recently in several European countries, which prompted the rise of politicians aiming at electoral gains by promoting anti-Europeanism or even xenophobia and racism. Confidence in state authorities has decreased significantly during the crisis period, increased the degree of dissatisfaction with the government and led to social protests, some extremely violent, especially in countries severely affected by economic crisis: Greece, Spain, Portugal, Italy. 
The report finds that the main causes of unhappiness among people were generated by decreasing incomes and rising unemployment. Not only those who actually had lost their jobs have been affected, but also their relatives or friends. The threat of unemployment was a cause of anxiety that had a negative influence over the people's level of health.

\section{Situation in Europe}

In the European Union, the same report finds that the living standards of economically, socially and institutions, continued to close between West and East, albeit at a rather slow pace. In this regard, another report conducted in 2011 by the Department of European Economic Studies College of Europe, entitled „Can policies make us happier?” stated that this economic convergence between Western and Eastern European Union has not resulted in a similar way to rapid increase satisfaction for the citizens of Central and Eastern European countries. Determinants of different degrees of happiness in the countries of Central and Eastern Europe, the report found, were: corruption, government spending and decentralization. „A decade after the fall of the Berlin Wall there were two important characteristics which defined Central and Eastern Europeans (CEE) vis-à-vis Western Europeans: they were (i) significantly poorer and (ii) more miserable.Today, the majority of the inhabitants of the $10 \mathrm{CEE}$ member states of the EU (EU10) remain poorer, but their income levels have converged rapidly towards those of Western Europe. Despite significant difficulties during the transition from a system of planned economy to market capitalism, in less than two decades, the EU10 countries have managed, to varying degrees, to build working institutions, establish the rule of law and run relatively successful economies, achieving high growth rates. By contrast, there is little evidence of convergence in life satisfaction. By and large, Central and Eastern Europeans remain as miserable as they were 10 years after the fall of the Wall" (Rodríguez-Pose \& Maslauskaite 2011, 1). „The fact that corruption levels remained roughly the same throughout a period of rapid economic growth only made matters worse. Our analysis shows that lower levels of corruption would have not only boosted GDP growth even further but would have also improved happiness levels substantially. The policy implication is quite straightforward. Unless governments in the region start tackling corruption seriously, their populations will remain unhappy. By contrast, decentralization in many countries in EU10 is becoming a non-negligible source of improvements in life satisfaction" (RodríguezPose \& Maslauskaite 2011, 25).

The report of the College of Europe also finds that the workforce in the Central and Eastern European countries became highly mobile after joining the EU, which influenced the low level of unemployment in these countries, many citizens of these countries finding work and Western richer states. But labor exodus from the East to the West also had negative cost, many families being separated in this way, which caused an overall decline in the level of happiness in these countries (Rodríguez-Pose \& Maslauskaite 2011, 2). And because we have reached this topic, it should be stressed that the Charter of Fundamental Rights of the European Union, art. 45 provides that „every citizen of the Union has the right to move and reside freely within the territory of Member States." A right that some politicians seem to have forgotten, if we think of populist rhetoric against immigrants generated by the political leaders in Britain and France, who seek to obtain electoral gains (UKIP party in Britain or the National Front in France, to give just two examples) by sending messages against citizens of other EU member states who seek happiness in these countries, forgetting that many British and French citizens who have chosen to live in other countries are not treated in a similar way.

Of course, we can question ourselves whether it would be right for happiness to be specially included within the Charter of Fundamental Rights of the EU? For this to happen, perhaps we would need instruments capable of measuring the level of happiness. As we have already seen, some states, by means of their governments, have begun to look for indicators to measure the level of happiness of their citizens. As we have already emphasized, reports about the degree of happiness globally have been issued. International organizations (UN, OECD) are seeking to define criterias which would help to determine, as precisely as possible, the degree of happiness. Public policies able to offer people the need to seek happiness may be developed on the basis of objective criterias, as this principle has been stated by the Founding Fathers of the United States Declaration of Independence, 1776: „We hold 
these truths to be self-evident, that all men are created equal, that they are endowed by their Creator with certain unalienable Rights, that among these are Life, Liberty and the pursuit of Happiness" (The United States Declaration of Independence 1776).

The relatively recent dispute on limiting migration in the United Kingdom has brought attention of the European public debate on citizens' rights that are enshrined in the Charter of Fundamental Rights. Even if the pursuit of happiness is one of the rights in the Charter, there are a number of rights which, taken together, could be interpreted as a corollary of that right. British citizens' right to seek happiness in other EU countries is equal to the right of citizens from other EU countries (Romanian included) to seek happiness in the UK.

Coming back to the issue of including the right to the pursuit of happiness in the EU Charter of fundamental rights, it must be said that there are already proposals in this regard. During a philosophical Symposium held in Athens in July 2014, the European Union Declaration on the right to happiness (Pallini Declaration) has been adopted. The document states that: "Given the fact that the right to pursue happiness is not included in the 54 articles of the Charter of Fundamental Rights of the European Union (2010/C 83/02), we ask for the recognition of this right of happiness in the European Union, since it is self-evident that it is a fundamental human right and its non-recognition in any part of the world constitutes the violation of this natural right" (Declaration of the right of happiness in the European Union 2014).

\section{Security challanges}

In the context of numerous armed conflicts that broke out in the world in recent years, the question arises whether or not wars can contribute to economic growth? A report called „Life beyond growth - report 2011 - Alternative happiness and additions to GDP - measured increase as a concept for social progress the annual report of the Institute for the study of happiness, economy and society" (2011) found that when taking into criteria which take account of GDP, the statistics show that wars have contributed to economic growth in the United States due to goods and services produced and sold in impressive numbers. On the other hand, the wars in which the United States have been involved had enormous cost in casualties and material damages. This had an impact over the US economy, considering that resources directed towards producing weapons significantly generated different decreases in spending for social programmes that some American citizens needed. Finally, after more than a decade of wars in Afghanistan and Iraq, the United States decided to withdraw troops from the two countries.

Conflicts in the Arab world are likely to continue in the next period, if we mention only the conflict in Syria or the campaign against the terrorist organisation of Islamic State/ISIS. It is therefore expected that those conflicts would generate the need to continue to produce weapons, physical destruction and loss of life (Life Beyond Growth 2011, 53). In general terms, the war is not beneficial to human welfare or happiness condition. Even if the production of weapons contribute to GDP growth in the countries concerned(increased exports), we must not forget that wars and armed conflicts do not contribute to human welfare and happiness, if we consider the long-term costs arising destruction, loss of life and environmental degradation (Life Beyond Growth 2011, 54).

The security crisis related to Ukraine in turn has affected not only Ukrainian society but also the economies of some EU Member States, if we take into account that several EU countries depend in a high degree on the Russian gas. Russia's economy also suffered from sanctions imposed by the US and EU. Experts agree that the situation of insecurity in the area has a negative impact on investment and increasing defense budgets, especially in EU and NATO countries, which leads to reduced investment required to develop other sectors. Protests generated some years ago by the economic crisis in the US and some EU countries (Greece, Spain, Italy, Portugal) - the so-called „Occupy Wall Street" movementor the „Arab spring"- that led to the change of governments in some countries in North Africa - have shown that people's discontent is generated not only by elements that are related to material/economic wealth, but also by issues that may be considered related to the concept of happiness. 


\section{Conclusion}

If happiness is considered as a national goal, one question arises: can happiness be considered as one of the internationally recognized human rights? None of the 30 articles of the Universal Declaration of Human Rights adopted by the United Nations in 1948, is actually referring to happiness. Nonetheless, Article 25 states: „Everyone has the right to a standard of living adequate for his health and his family." However, the text adopted by the UN contains a number of other rights which some specialists believe that can bring happiness, such as the right to work, or the people's right to participate in decisions that may affect their lives (Life Beyond Growth 2011, 65).

Major events that have occurred in recent years, which affected a large part of the world, have changed the way we look at humanity. Political leaders, scientists, or what we usually call civil society, have contributed in recent years to impose a new perspective on what we used to call „world and life". The global economic crisis, natural disasters (earthquakes followed by tsunamis, floods etc.), armed conflicts that devastated many areas of the world have made us look differently at how we live our lives. Governments have begun to take seriously the new paradigm proposed by opinion leaders. And so it emerged in public debate (or rather re-emerged) the concept of happiness and the notion of living well (welfare).

What is of course really important is to agree on the usefulness of the idea that the right to happiness or the right to the pursuit of happiness can be considered a universal human right and therefore decide that states have public policies that seek to ensure conditions so that all their citizens to benefit from this right. This is why a number of authors undelined through the International Law doctrine that this right became part of the third generation of fundamental rights and liberties, the socalled ,solidarity rights".

\section{References}

Declaration of the right of happiness in the European Union, The Friends of Epicurean Philosophy "Garden" of Greece, 4th Pan-Hellenic Symposium of Epicurean Philosophy, Pallini, Athens, Greece, February 15, 2014; http://www.eudaimonia.eu/the-declaration/?lang=en.

EESC (European Economic and Social Committee). 2014. Let's Talk Happiness - beyond GDP'. 13 June 2014. http://www.eesc.europa.eu/?i=portal.en.events-and-activities-happiness.

Life Beyond Growth. 2011. Alternatives and Complements to GDP-Measured Growth as a Framing Concept for Social Progress, 2012 Annual Survey Report of the Institute for Studies in Happiness, Economy, and Society, ISHES (Tokyo, Japan) - 53; http://rio20.net/wp-content/uploads/2012/03/LifeBeyondGrowth.pdf.

Rodríguez-Pose, Andrés \& C. Maslauskaite. 2011. "Can Policy Make Us happier? Individual characteristics, socioeconomic factors, and life satisfaction in Central and Eastern Europe." Cambridge Journal of Regions, Economy and Society, Volume 5, Issue 1., https://academic.oup.com/cjres/article/5/1/77/326486.

Stiglitz, Joseph E., Sen, Amartya K., \& Fitoussi, Jean-Paul. 2009. Report by the commission on the measurement of economic performance and social progress. Commission on the Measurement of Economic Performance and Social Progress, Paris. https://ec.europa.eu/eurostat/documents/118025/118123/Fitoussi+Commission+report.

The United States Declaration of Independence, 1776. US History. Available at http://www.ushistory.org/declaration/document/.

UN General Assembly Resolution 65 /309. 2011. Happiness: towards a holistic approach to development: Resolution 65 /309, adopted by the General Assembly, available from https://digitallibrary.un.org/record/715187.

UN Secretary-General Ban Ki-moon's message. 2013. "By Contributing to Common Good, We Ourselves Are Enriched, Secretary-General Says in Message for Inaugural International Day of Happiness." https://www.un.org/press/en/2013/sgsm14872.doc.htm.

World Happiness Report 2013. Helliwell, John F., Richard Layard, and Jeffrey Sachs, eds. 2013. World Happiness Report 2013. New York: UN Sustainable Development Solutions Network, http://unsdsn.org/wpcontent/uploads/2014/02/WorldHappinessReport2013_online.pdf. 